\title{
Soil and Crop Micronutrient Concentrations as Modified by Wastewater Sludge
}

\author{
McGonigle, Terence P. (Corresponding author) \\ Department of Biology, Brandon University \\ 270-18th Street, Brandon, Manitoba R7A 6A9, Canada \\ E-mail: mcgoniglet@brandonu.ca \\ Evans, Leslie J. \\ School of Environmental Sciences, University of Guelph \\ Guelph, Ontario, N1G 2W1, Canada \\ Wells, Chris J. \\ Du Pont Canada Inc. \\ P.O. Box 611, Maitland, Ontario, K0E 1P0, Canada
}

Received: June 19, 2014 Accepted: June 28, $2014 \quad$ Published: October 14, 2014

doi:10.5296/jee.v5i2.5831ＵRL: http://dx.doi.org/10.5296/jee.v5i2.5831

\begin{abstract}
Soil extracts are used to provide a measure of plant nutrient bioavailability, but their predictive capacity is variable. In a greenhouse experiment, soil was amended with sewage sludge from textile manufacturing wastewater. We investigated the correspondence between maize (Zea mays L.) shoot uptake and concentrations in soil extractions for plant essential micronutrients concentrated in the sludge: $\mathrm{B}, \mathrm{Cu}, \mathrm{Mn}$, and $\mathrm{Zn}$. Hot water extract was used for $\mathrm{B}$, whereas diethylene triamine pentaacetic acid (DTPA) extract was used for $\mathrm{Cu}, \mathrm{Mn}$, and $\mathrm{Zn}$. Separate pots with $\mathrm{NH}_{4} \mathrm{NO}_{3}$ amendment, but no sludge, allowed comparison of soil micronutrient extraction and plant uptake under conditions of elevated mineral $\mathrm{N}$ fertility similar to those with sludge amendment, but in the absence of sludge. Addition of sludge did not change soil extractable concentrations nor shoot concentrations of B and $\mathrm{Zn}$. B was
\end{abstract}


abundant in the sludge but likely remained strongly bound as organic complexes, whereas the quantity of $\mathrm{Zn}$ was not high enough to register difference. Shoot Mn was increased by both sludge amendment and an $\mathrm{NH}_{4} \mathrm{NO}_{3}$ effect, likely from $\mathrm{pH}$ decrease associated with nitrification of the ammonium in the sludge and in the fertilizer. DTPA-extractable Mn increased in sludge-amended plots. DTPA-extractable $\mathrm{Cu}$ increased strongly following sludge amendment, but, in contrast to $\mathrm{Mn}$, shoot $\mathrm{Cu}$ concentration was not changed. Thus, selectivity of roots to avoid $\mathrm{Cu}$ is not revealed by DTPA. The correspondence between extraction-based estimation of availability and the actual plant uptake varies among micronutrients due to effects of soil conditions and selectivity of roots.

Keywords: DTPA, Hot-water extract, Boron, Copper, Manganese, Zinc 


\section{Introduction}

Sewage sludges generated from the treatment of waste streams in municipal and industrial installations are often applied to agricultural land for disposal or to supply $\mathrm{N}$ for crops uptake (Binder et al., 2002; Gilmour et al., 2003). For example, 30\% of sludge is applied to agricultural land in Japan (Ito et al., 2000). In addition to $\mathrm{N}$, sludges often contain micronutrients that could benefit crop growth (Abdou and El-Nennah, 1980; Perez-Murcia et al., 2006; Vazquez et al., 2003). However, metal loadings to soil from repeated sludge applications can cause reduced numbers of nitrogen fixing bacteria in soil (McGrath et al., 1988; McGrath et al., 1995) and result in a shortage of arbuscular mycorrhizal fungi (del Val et al., 1999). In contrast, Kunito et al. (2001) found no impact of historic sludge applications on microbial biomass carbon or soil enzyme activities. The presence of metals in sludge is one of the main concerns linked to the regulation of sludge application (Davis, 1993; Goda et al., 1986). Concerns about pathogens have caused irradiation of sludge, but this process increases plant availability of $\mathrm{Zn}$ (Wen et al., 2002a) and $\mathrm{Cu}$ (Wen et al., 2002b).

Textile-manufacture generates sewage sludge at the DuPont installation at Maitland, Ontario, Canada. The Maitland sludge is bulked with $\mathrm{FeCl}_{3}$ and has part of the water removed by application of physical pressure to form a moist cake. Release of mineral $\mathrm{N}$ from the Maitland sludge offers promise for use of this material in agricultural fields (McGonigle et al., 2012).

Evaluation of nutrient availability can be assessed by measuring the uptake of the nutrients to a test plant or by use of soil extractants. The chelating agent diethylene triamine pentaacetic acid (DTPA) has been widely used as soil extractant to estimate plant-available levels of $\mathrm{Cu}$, Mn, and Zn (Barbarick and Workman, 1987; Jiang et al., 2008; Sharma et al., 2000). DTPA is a chelating agent that binds to the free-ions of these metals and reduces their activity in solution, thereby mimicking plant uptake and stimulating the replenishment of the metal ions in solution from the solid phase (Sims and Johnson, 1991). Although DTPA extraction has been shown to be effective to test for available B (Matsi et al., 2000), the hot-water method (Bell, 1997) is the established method for determination of extractable B in combination with inductively coupled plasma (ICP) or spectrophotometric determination (Sah and Brown, 1997). DTPA-extractable soil concentrations of $\mathrm{Cu}, \mathrm{Mn}$, and $\mathrm{Zn}$, as well as hot-water extractable B, are often significantly correlated with plant uptake of these elements (Sims and Johnson, 1991). However, soil conditions are expected to modify availability in soil of $\mathrm{B}, \mathrm{Cu}$, Mn, and Zn (Evans et al., 1995; Wu et al., 2001).

The aims of this study were two-fold: first, to determine the plant uptake of the four micronutrients most abundant in the Maitland industrial sludge, namely $\mathrm{B}, \mathrm{Cu}, \mathrm{Mn}$, and $\mathrm{Zn}$; second, to explore the relationships between that plant uptake and the levels in soil of these elements as determined by soil extraction. $\mathrm{N}$ fertilizer was a second treatment factor in addition to sludge amendment. The sludge adds micronutrients but is also expected to provide a significant amount of ammonium, which can undergo nitrification and modify soil $\mathrm{pH}$ locally (Brady and Weil, 2008). Thus, the parallel use of $\mathrm{N}$ fertilizer in separate pots was employed to assess the impact of mineral $\mathrm{N}$ addition on the availability of micronutrients 
already present within the studied soil.

\section{Materials and Methods}

\subsection{Collection and Analysis of Materials}

The sludge used was in the form of a partially dewatered cake from the sewage treatment plant of Du Pont Canada Inc. at Maitland, Ontario, Canada. Triplicate samples of $0.5 \mathrm{~g}$ sludge were heated in $5 \mathrm{ml} 65 \%$ nitric acid in the following microwave sequence: 5 minutes at 250 $\mathrm{W}, 1$ minute at $0 \mathrm{~W}, 4$ minutes at $250 \mathrm{~W}$, and 7 minutes at $400 \mathrm{~W}$. Leachate was filtered using Whatman No. 42 paper and brought to a final volume of $100 \mathrm{ml}$ using ultrafiltration-purified water. Elemental composition of the sludge was determined by analysis of leachate using ICP optical atomic emission spectrometry (ICP-OES) at the Ministry of Northern Development of Mines, Sudbury, Ontario, Canada.

Soil was collected from the top $15-\mathrm{cm}$ of low-fertility plots at the Elora Research Station at $43^{\circ} 41^{\prime} \mathrm{N}$ and $80^{\circ} 14^{\prime} \mathrm{W}$ in Ontario, Canada. The silt loam at the site had a pH of 7.5 and is classified as a Gleyed Melanic Brunisol in the Canadian system of soil classification and as an Aquic Hapludalf in the United States Department of Agriculture Soil Taxonomy (Tollenaar et al., 1994). The particle size distribution was $30 \%$ sand, $50 \%$ silt, and $20 \%$ clay (Ketcheson, 1980). Soil was partially air-dried and passed through a 5-mm screen before use.

\subsection{Greenhouse Experiment}

Pre-soaked maize (Zea mays L.) seeds were grown for 24 days in pots in the greenhouse with soil amended with sludge at 100,200 , and $400 \mathrm{mg} \mathrm{N} \mathrm{kg}^{-1}$ dry soil. To ensure all pots had adequate $\mathrm{P}$ and $\mathrm{K}$, all soil was fertilized with $75 \mathrm{mg} \mathrm{P} \mathrm{kg}^{-1}$ as $\mathrm{Ca}\left(\mathrm{H}_{2} \mathrm{PO}_{4}\right) \cdot 2 \mathrm{H}_{2} \mathrm{O}$ and $50 \mathrm{mg} \mathrm{K}$ $\mathrm{kg}^{-1}$ as $\mathrm{K}_{2} \mathrm{SO}_{4}$. Pots were $16 \mathrm{~cm}$ and $14 \mathrm{~cm}$ diameter at the soil surface and base, respectively. Pots were filled to $10 \mathrm{~cm}$ depth with a bulk density of $1.1 \mathrm{~g} \mathrm{~cm}^{-3}$. Dry mass of soil was 1.95 $\mathrm{kg} \mathrm{pot}^{-1}$. As well as controls, $\mathrm{NH}_{4} \mathrm{NO}_{3}$ was added to separate pots at rates of 25,50 , and 75 $\mathrm{mg} \mathrm{N} \mathrm{kg}^{-1}$ dry soil, to give seven treatments in all. There were four replicates of each treatment to give a total of 28 pots arranged in a randomized complete block design. Six seeds were sown per pot, with thinning to four seedlings per pot after one week. Pots were watered daily to gravimetrically maintain $0.23 \mathrm{~g} \mathrm{H}_{2} \mathrm{O} \mathrm{g}^{-1}$ dry soil.

At harvest, all shoots were removed by cutting 5-mm above the soil surface. Two 33-mm diameter soil cores were then taken from each pot approximately mid-way between shoot bases, about half the distance from the center to the edge of the pot, and to the full pot depth. One core was selected at random from each pot and used to wash out roots on a $0.1-\mathrm{mm}$ screen. The soil from the second core from each pot was sieved on a 2 -mm screen, discarding roots, stones, and organic debris. This sieved soil was used for analysis of micronutrients, as described below. Although it is customary to evaluate soil for macronutrients at planting, soil for analysis of micronutrients was collected at harvest, rather than at setup, to ensure that the root environment of the plant was characterized following equilibration of amendments with soil during the 24-day growth period.

Plant tissues taken at 24 days of growth were dried to constant mass at $70^{\circ} \mathrm{C}$. Dried shoot and 
root was digested for metal analysis in concentrated acids in a procedure modified from Thomas et al. (1967). Briefly, tissues were digested by heating $0.25 \mathrm{~g}$ oven-dried powder in 5 $\mathrm{ml}$ concentrated $\mathrm{H}_{2} \mathrm{SO}_{4}$ at reflux for 60 minutes, followed by adding up to an approximate total of $0.5 \mathrm{ml} \mathrm{H}_{2} \mathrm{O}_{2}$ in two or three aliquots while heating for about another 30 minutes or until clear, followed by heating for an additional 20 minutes, cooling, and bringing up to a final volume of $25 \mathrm{ml}$ using ultrafiltration-purified water. Root and shoot digests were analyzed for $\mathrm{Zn}, \mathrm{Cu}$, and $\mathrm{Mn}$ by atomic abortion spectrometry (AAS) using a Varian Spectra AA300. Shoot B was determined by dry-ashing $0.25 \mathrm{~g}$ samples of oven-dried powdered shoot overnight at $480^{\circ} \mathrm{C}$ in a muffle furnace, followed by taking the ashes up into $12.5-\mathrm{ml} 0.4 \mathrm{M}$ $\mathrm{HCl}$ and filtering through Whatman No.42 filter paper. The concentration of B in solution in the dry-ash digests was determined spectrophotometrically using an autoanalyser system employing the reaction of B with azomethine-H (Wolf, 1971). Insufficient root material prevented analysis of root concentration of B.

To determine soil extractable concentrations of $\mathrm{Cu}, \mathrm{Mn}$, and $\mathrm{Zn}$, samples of 10-g dry soil were shaken in a 2:1 ratio of extract to soil with an extract solution of $0.005 \mathrm{M}$ DTPA in 0.01 $\mathrm{M} \mathrm{CaCl}_{2}$, adjusted to $\mathrm{pH} 7.3$ with dilute $\mathrm{HCl}$ (Liang and Karamanos, 1993). $\mathrm{Cu}, \mathrm{Mn}$, and $\mathrm{Zn}$ concentrations in soil were determined for the DTPA extracts using AAS. Extractable soil B was estimated using the hot-water extract system (Gupta, 1967), substituting $0.01 \mathrm{M} \mathrm{CaCl}_{2}$ for the water. Samples of $20 \mathrm{~g}$ dry soil were boiled in $40 \mathrm{ml}$ of $0.01 \mathrm{M} \mathrm{CaCl}_{2}$ for 5 minutes, allowed to cool for 5 to 10 minutes, and passed through Whatman No.42 filter paper. The concentrations of $\mathrm{B}$ in solution for the soil extracts were determined using ICP-OES. The sludge was expected to contain abundant Fe from the precipitation process. However, Fe was not determined for the soil or plant tissues, because the soil has no history of Fe deficiency for maize.

\subsection{Numerical Analysis}

Maximum shoot biomass was determined as $\mathrm{y}$ when $\mathrm{x}=-\mathrm{b} / 2 \mathrm{c}$ for the quadratic regression $\mathrm{y}=$ $\mathrm{a}+\mathrm{bx}+\mathrm{cx}^{2}$ for $\mathrm{x}$ as $\mathrm{N}$ added. Treatment means were separated using the Tukey test for $\mathrm{P}=$ 0.05 following randomized complete block analysis of variance (Zar, 2010).

\section{Results}

Sludge analyses as determined here are expressed on a dry biomass basis, with mean adjusted by standard deviation (s.d., $\mathrm{n}=3$ ) for triplicated samples. Values were $261 \pm 19 \mathrm{~g} \mathrm{C} \mathrm{kg}^{-1}$ and $40 \pm 5 \mathrm{~g} \mathrm{~N} \mathrm{~kg}^{-1}$ giving $6.6 \pm 1.2$ for the $\mathrm{C}: \mathrm{N}$ ratio. Mineral $\mathrm{N}$ extractable from sludge in a $1: 1$ ratio of $2.0 \mathrm{M} \mathrm{KCl}$ was $1.49 \pm 0.04 \mathrm{~g} \mathrm{NH}_{4}-\mathrm{N} \mathrm{kg}^{-1}$ and $0.020 \pm 0.003 \mathrm{~g} \mathrm{NO}_{3}-\mathrm{N} \mathrm{kg}^{-1}$. Moisture

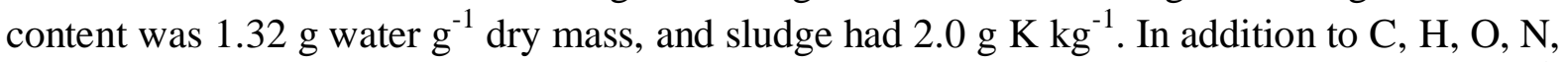
$\mathrm{K}$, and $\mathrm{S}$, the sludge macronutrients at high concentration were in the form of $\mathrm{P}$ at $5.3 \mathrm{~g} \mathrm{~kg}^{-1}$, $\mathrm{Ca}$ at $3.5 \mathrm{~g} \mathrm{~kg}^{-1}$, and $\mathrm{Mg}$ at $1.5 \mathrm{~g} \mathrm{~kg}^{-1}$ while $\mathrm{Fe}$ was $8.2 \pm 0.3 \mathrm{~g} \mathrm{~kg}^{-1}$. Plant-essential micronutrients other than Fe exceeding $100 \mathrm{mg} \mathrm{kg}^{-1}$ in the sludge were $498 \pm 79 \mathrm{mg} \mathrm{B} \mathrm{kg}{ }^{-1}$, $1004 \pm 43 \mathrm{mg} \mathrm{Cu} \mathrm{kg}^{-1}, 838 \pm 143 \mathrm{mg} \mathrm{Mn} \mathrm{kg}^{-1}$, and $129 \pm 16 \mathrm{mg} \mathrm{Zn} \mathrm{kg}^{-1}$. A complete sludge analysis was given in McGonigle et al. (2012).

At harvest, control pots had 5.9 leaves plant ${ }^{-1}$, whereas all other pots had in the range 6.8-7.0 
leaves per plant ${ }^{-1}$. Shoot growth in the greenhouse experiment responded when $\mathrm{N}$ was added either as $\mathrm{NH}_{4} \mathrm{NO}_{3}$ (Fig. 1a) or as sludge (Fig. 1b). Based on a quadratic regression, maximum shoot biomass was obtained when $\mathrm{NH}_{4} \mathrm{NO}_{3}$ was added at $95 \mathrm{mg} \mathrm{N} \mathrm{kg}^{-1}$ and with sludge when added at $270 \mathrm{mg} \mathrm{N} \mathrm{kg}^{-1}$.

(a)

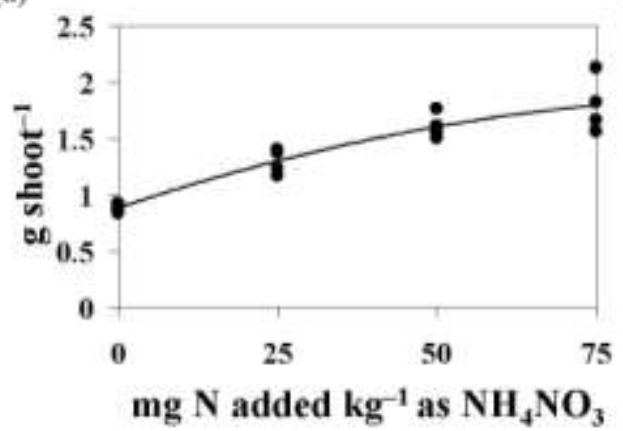

(b)

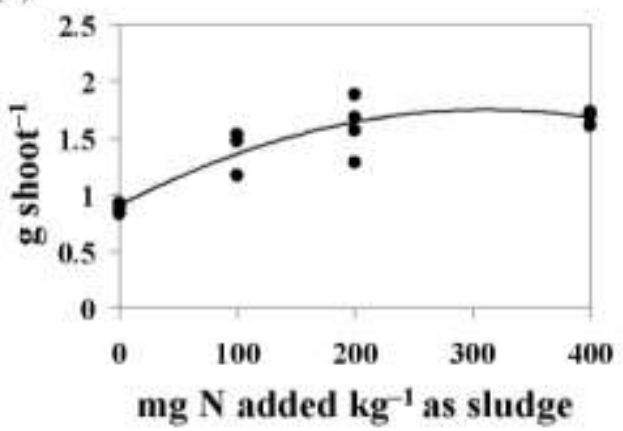

Figure 1. Shoot dry mass at 28 days for maize raised in soil in pots with rates of $\mathrm{N}$ amendment in the form of (a) $\mathrm{NH}_{4} \mathrm{NO}_{3}$ at 25,50 , and $75 \mathrm{mg} \mathrm{N} \mathrm{kg}^{-1}$ dry soil, or as (b) sludge at 100, 200, and $400 \mathrm{mg} \mathrm{N} \mathrm{kg}^{-1}$ dry soil. (Fitted curves are: for $\mathrm{NH}_{4} \mathrm{NO}_{3}, \mathrm{y}=0.88+0.019 \mathrm{x}-0.0001 \mathrm{x}^{2}$ with $\mathrm{r}^{2}=0.88$; and for sludge, $\mathrm{y}=0.90+0.0054 \mathrm{x}-0.00001 \mathrm{x}^{2}$ with $\mathrm{r}^{2}=0.84$ )

(a)

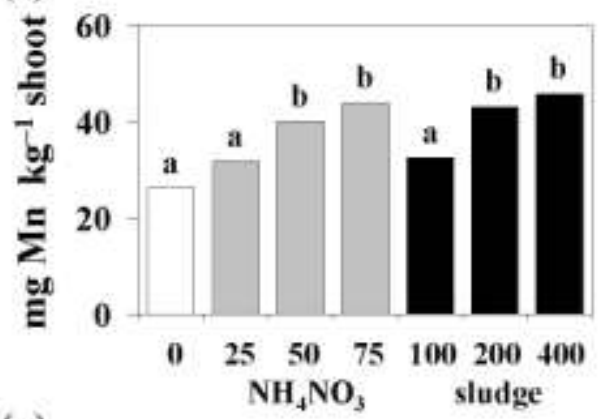

(c)

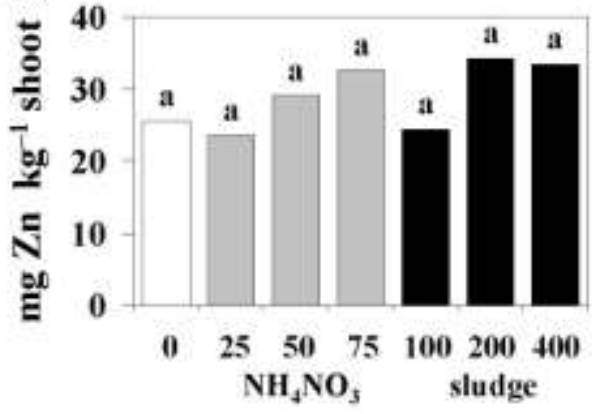

(b)

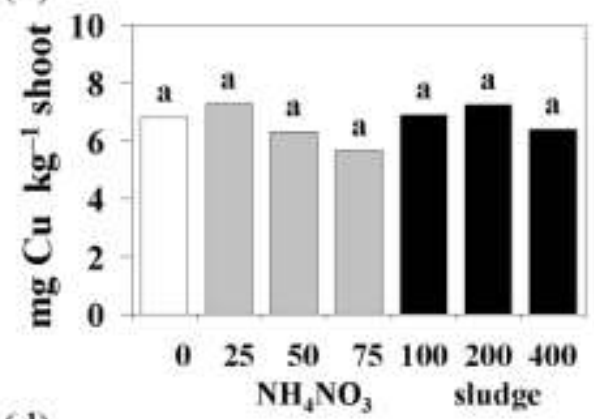

(d)

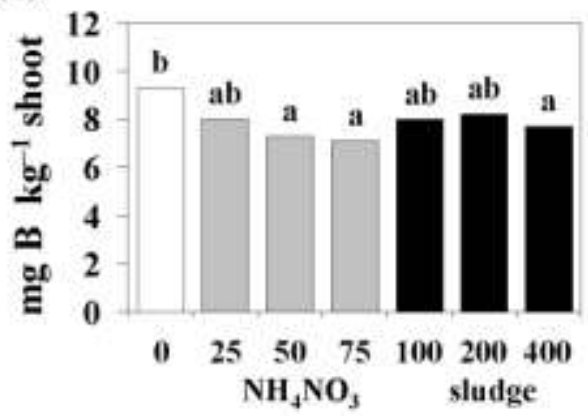

Figure 2. Effect of fertilizer and sludge amendments, at rates indicated in $\mathrm{mg} \mathrm{N} \mathrm{kg}^{-1}$ dry soil, as compared to the control treatment with no amendment, on maize shoot concentrations at 28 days of (a) Mn, (b) $\mathrm{Cu}$, (c) $\mathrm{Zn}$, and (d) B. (Means with different letters are significantly different at

$$
\mathrm{P}=0.05 ; \mathrm{n}=4)
$$

Shoot concentrations of $\mathrm{Cu}$ and $\mathrm{Zn}$ did not increase with any of the treatments, whereas shoot 


\section{Macrothink}

Mn concentrations increased in response to both sludge and fertilizer applications (Fig. 2). Shoot B concentration decreased in association with the greater growth in pots with the higher levels of fertilizer as well as sludge applications (Fig. 2). Shoot content of B, Cu, Mn, and $\mathrm{Zn}$ increased with $\mathrm{NH}_{4} \mathrm{NO}_{3}$ and sludge amendments (Fig. 3). Root concentrations of $\mathrm{Cu}$, $\mathrm{Mn}$, and $\mathrm{Zn}$ did not respond to treatments. Overall mean $(\mathrm{n}=28)$ root concentrations of $\mathrm{Mn}$, $\mathrm{Cu}$ and $\mathrm{Zn}$ were $253 \pm 15 \mathrm{mg} \mathrm{kg}^{-1}, 206 \pm 59 \mathrm{mg} \mathrm{kg}^{-1}$, and $163 \pm 110 \mathrm{mg} \mathrm{kg}^{-1}$ respectively.

(a)

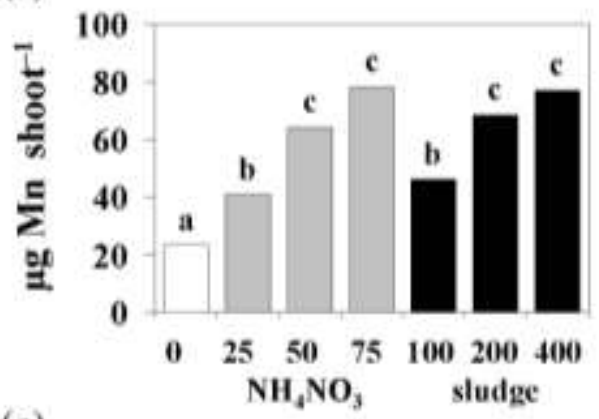

(c)

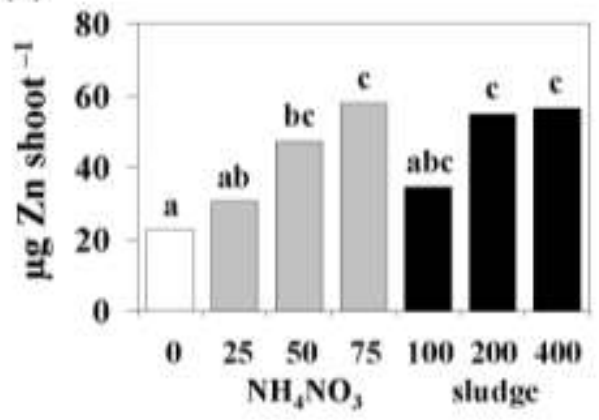

(b)

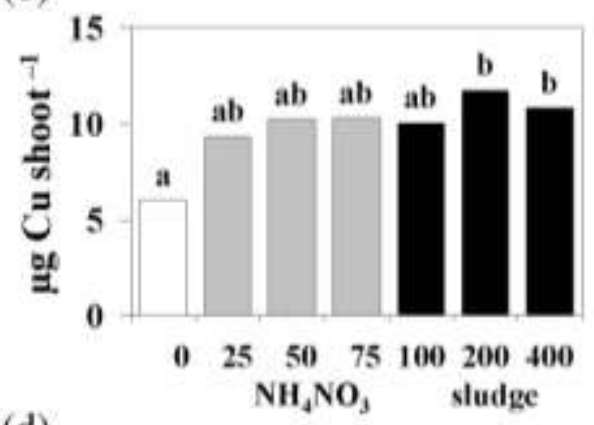

(d)

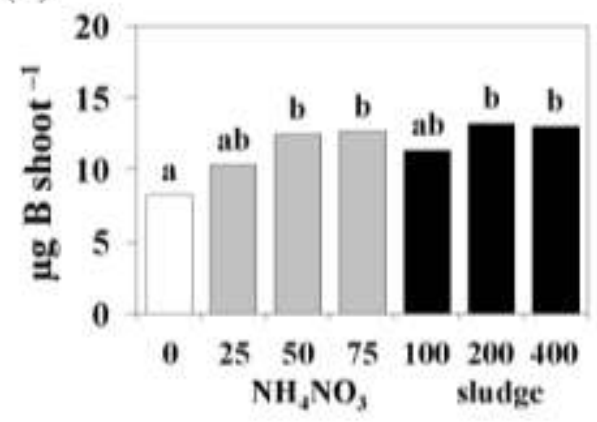

Figure 3. Effect of fertilizer and sludge applications, at rates indicated in $\mathrm{mg} \mathrm{N} \mathrm{kg}^{-1}$ dry soil, as compared to the control treatment on maize shoot content at 28 days of (a) $\mathrm{Mn}$, (b) $\mathrm{Cu}$, (c)

$\mathrm{Zn}$, and (d) B. (Means with different letters are significantly different at $\mathrm{P}=0.05 ; \mathrm{n}=4$ )

Extractable soil $\mathrm{B}$ and $\mathrm{Zn}$ were not changed by the sludge treatment, contrasting with the extractable soil $\mathrm{Cu}$ in response to the sludge amendments (Fig. 4), even though shoot $\mathrm{Cu}$ concentrations were not changed (Fig. 2). Increases in shoot Mn concentration (Fig. 2) were associated with an increase in extractable soil Mn as induced by sludge addition (Fig. 4). Increases in both extractable soil $\mathrm{Cu}$ and extractable soil $\mathrm{Mn}$ over that of the control were positively related to increments of sludge application (Fig. 5). A logarithmic trend accounted for Mn (Fig.5a) concentration, while a linear relationship was seen for $\mathrm{Cu}$ (Fig. 5b). 
(a)

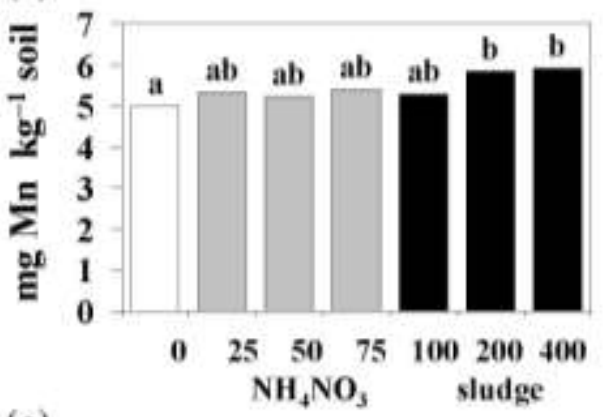

(c)

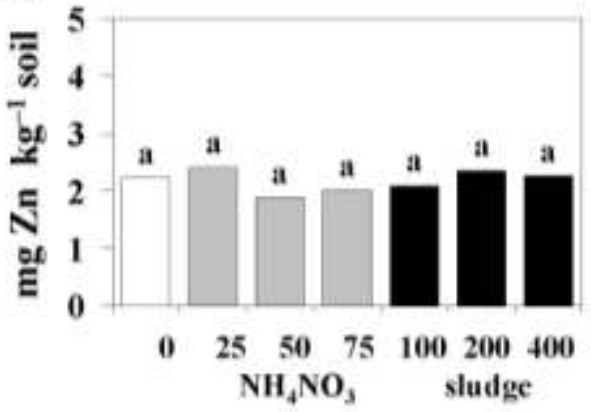

(b)

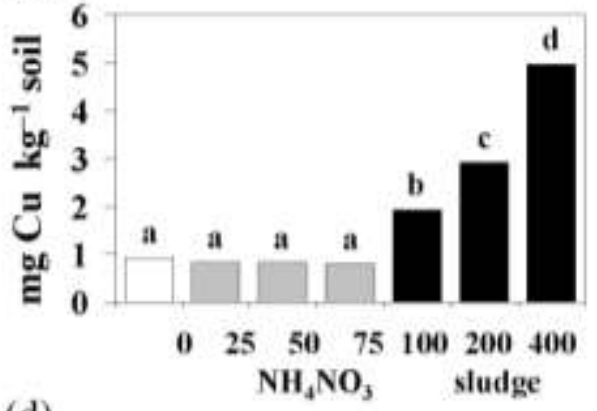

(d)

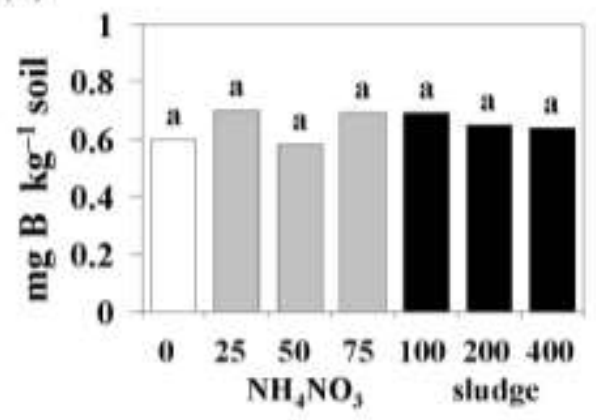

Figure 4. Effect of fertilizer and sludge amendments, at rates indicated in $\mathrm{mg} \mathrm{N} \mathrm{kg}^{-1}$ dry soil, as compared to the control treatment with no amendment, on soil concentrations determined by DTPA extraction at 28 days for (a) $\mathrm{Mn}$, (b) $\mathrm{Cu}$, (c) $\mathrm{Zn}$, and for hot-water extraction at 28 days for (d) B. (Means with different letters are significantly different at $\mathrm{P}=0.05 ; \mathrm{n}=4$ )

(a)

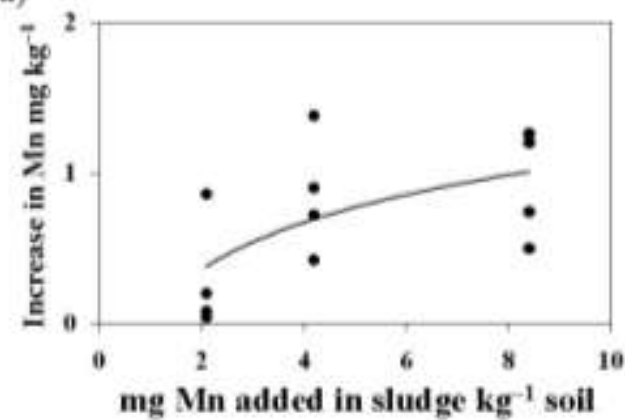

(b)

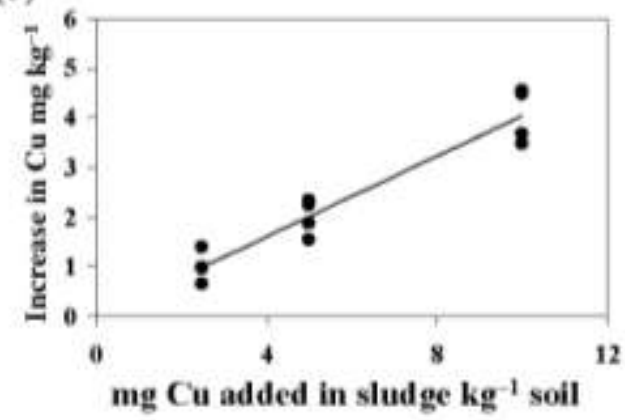

Figure 5. Increase in DTPA-extracted soil levels over the control at 28 days in relation to the rate of element applied in sludge for (a) $\mathrm{Mn}$ and (b) $\mathrm{Cu}$. (Fitted lines are as follows: for $\mathrm{Mn}, \mathrm{y}=0.04$ $+0.45 \ln \mathrm{x}$ with $\mathrm{r}^{2}=0.35$; for $\mathrm{Cu}, \mathrm{y}=! 0.03+0.41 \mathrm{x}$ with $\mathrm{r}^{2}=0.92$ was significant $(P<0.001)$. The corresponding linear regression for $(\mathrm{a})$ with $\ln (\mathrm{x}$-axis $)$ was $(\mathrm{P}=0.043)$ significant $)$

\section{Discussion}

The Maitland sludge cake had concentrations of $\mathrm{P}, \mathrm{Fe}, \mathrm{Ca}, \mathrm{Mg}$, and $\mathrm{Zn}$, that were one-fifth to one-tenth of the size of the means, and a $\mathrm{Cu}$ concentration close to the mean, for 250 sludges (Sommer, 1977). However, the Mn concentration of $835 \mathrm{mg} \mathrm{kg}^{-1}$ for the Maitland sludge was over twice as high as the mean of $380 \mathrm{mg} \mathrm{kg}^{-1}$, and the B concentration of $486 \mathrm{mg} \mathrm{kg}^{-1}$ for the Maitland sludge was six times the mean of $77 \mathrm{mg} \mathrm{kg}^{-1}$, for the same 250 sludges (Sommer, 
1977). Concentrations for $\mathrm{Cu}$ and $\mathrm{Zn}$ for the Maitland sludge fell within the ranges of values reported elsewhere (Barbarick and Workman, 1987).

The growth response to additions of $\mathrm{N}$ increased in a convex manner to a maximum, in keeping with established response patterns (Cerrato and Blackmer, 1990; Tisdale et al., 1985). According to the regression analysis, experimental addition of the highest rate of $75 \mathrm{mg} \mathrm{N}$ $\mathrm{kg}^{-1}$ in the form of $\mathrm{NH}_{4} \mathrm{NO}_{3}$ took growth close to maximum biomass, which would have needed $95 \mathrm{mg} \mathrm{N} \mathrm{kg}^{-1}$ as $\mathrm{NH}_{4} \mathrm{NO}_{3}$ to be reached. Maximum growth was seen in response to $\mathrm{N}$ in sludge at $270 \mathrm{mg} \mathrm{N} \mathrm{kg}^{-1}$, close to three times the rate of application of inorganic fertilizer for maximum growth. These responses validate the selection of rates of amendment for $\mathrm{NH}_{4} \mathrm{NO}_{3}$ and sludge insofar as a greater application rate of sludge than fertilizer was needed to achieve comparable growth.

Micronutrient concentrations in whole maize plants of the age studied are given as sufficient in the range 1-13 $\mathrm{mg} \mathrm{kg}^{-1}$ for $\mathrm{B}$ and $8-15 \mathrm{mg} \mathrm{kg}^{-1}$ for $\mathrm{Cu}$ (Jones et al., 1990). Thus, concentrations of $\mathrm{B}$ and $\mathrm{Cu}$ in all maize plants in the greenhouse experiment were in the range normally seen for healthy maize. However, concentrations of $\mathrm{Mn}$ in the plants studied here fell below the sufficiency range, given as 40-150 $\mathrm{mg} \mathrm{kg}^{-1}$ (Jones et al., 1990), except at the two highest levels of application of $\mathrm{NH}_{4} \mathrm{NO}_{3}$ and sludge. Lack of sufficiency in control plants for Mn but sufficiency in control plants for $\mathrm{B}$ and $\mathrm{Cu}$ is consistent with the positive response to the amendments seen for shoot $\mathrm{Mn}$ concentration but absent for shoot concentrations of $\mathrm{B}$ and $\mathrm{Cu}$. Shoot concentrations of $\mathrm{Zn}$ were close to the low end of the corresponding sufficiency range, given as 30-60 mg kg${ }^{-1}$ (Jones et al., 1990), and no response of $\mathrm{Zn}$ concentration was seen in response to the amendments.

Increased shoot Mn, which was seen in all pots relative to the controls, was probably caused by localized reduction in soil $\mathrm{pH}$ by nitrification. All treated pots had increased levels of ammonium, either through amendment with inorganic fertilizer or with sludge, and that ammonium underwent conversion to nitrate during the period of plant growth (McGonigle et al., 2012). Nitrification leads to acidification (Brady and Weil, 2008), and acidity promotes reduction of manganese dioxide to divalent manganese cations, which are more soluble than tetravalent manganese cations (Marschner, 1995). Although wholesale reduction of $\mathrm{pH}$ in the pots is unlikely, localized pockets within the soil volume likely had reduced $\mathrm{pH}$, increasing manganese solubility markedly (Bromfield et al., 1983). Lettuce (Lactuca sativa L.) shoot concentration of $\mathrm{Mn}$ was also found to increase in response to sludge addition to greenhouse pots (Hue et al., 1988). However, in contrast to the present study, no change in shoot Mn was found in response to addition of urea to the soil sown to lettuce (Hue et al., 1988). The interpretation made was that increased $\mathrm{Mn}$ was from decomposition of sludge combined with $\mathrm{pH}$ reduction from organic acids in the sludge (Hue et al., 1988). In contrast, decreased soybean (Glycine $\max$ (L.) Merr.) shoot concentration of Mn was found after sludge amendment, and was attributed to a tissue dilution effect linked to growth stimulation (Reddy and Dunn, 1983). The curvilinear response of increase in extracted soil Mn to mass of Mn added in sludge (Fig. 5a) supports the interpretation that a change in conditions, rather than the quantity added, caused the increased availability; we see in contrast the situation for $\mathrm{Cu}$ (Fig. 5b), where the corresponding linear response shows that extraction availability was 
proportional to the quantity added.

Taken together with no change in shoot concentration of $\mathrm{B}$, the absence of a change in extractable soil $\mathrm{B}$ in response to the sludge amendments indicated that the sludge content of B was not available to plants and/or was in a stable form. Boron has been shown to form strong complexes with organic matter in soil (Yermiyahu, 1995), in particular via boron-diol complexes (Goldberg, 1997). Binding of B to sludge has been quantified in terms of absorption capacity (Fujita et al., 2005).

Although the increase in soil-extractable $\mathrm{Cu}$ was linear in response to sludge addition (Fig. $5 b$ ), none of this $\mathrm{Cu}$ was recovered in the plants. Even with the highest rate of sludge amendment, the level of soil $\mathrm{Cu}$ was still within the range of values recorded for many soils in Eastern Canada (Whitby et al., 1978). The lack of correspondence between extractable $\mathrm{Cu}$ and concentrations of this element in shoots is in keeping with the wide range of recoveries for soil $\mathrm{Cu}$ found for various chelating agents (Flores-Valez et al., 1996). Increased DTPA-extractable $\mathrm{Cu}$ but no response of shoot $\mathrm{Cu}$ to sludge addition, as found here for maize and for lettuce (Hue et al., 1988). In contrast, soybean shoot $\mathrm{Cu}$ concentration and DTPA-extractable $\mathrm{Cu}$ both increased following sludge amendment elsewhere (Reddy and Dunn, 1983). Soil levels of DTPA-extractable $\mathrm{Cu}$ were higher in the soybean study (Reddy and Dunn, 1983), reaching $11 \mathrm{mg} \mathrm{kg}^{-1}$, compared to only $5 \mathrm{mg} \mathrm{kg}^{-1}$ in the present study. It is not certain if the highest soil $\mathrm{Cu}$ levels, or the use of soybean rather that maize as test plant, caused increased shoot uptake of $\mathrm{Cu}$ in the previous work (Reddy and Dunn, 1983). Estimating bioavailability of $\mathrm{Cu}$ in soils has been approached using a bioassay consisting of a soil block inserted below Brassica napus L. otherwise raised under standardized hydroponic conditions (Chaignon and Hinsinger, 2003).

Responses of soil and shoot $\mathrm{Zn}$ to sludge amendments varied among previous studies. No changes in shoot $\mathrm{Zn}$ concentration or DTPA-extractable $\mathrm{Zn}$ as found in current study for maize was in contrast with corresponding increases for both of these properties in the study of lettuce response to sludge amendment (Hue et al., 1988), as well as in a field study for maize (Bidwell and Dowdy, 1987). An increase in DTPA-extractable Zn was seen following sludge addition to soybean, but no change accounted for shoot $\mathrm{Zn}$ (Reddy and Dunn, 1983).

\section{Conclusion}

Soil extractions to assess availability for B and $\mathrm{Zn}$ were consistent with plant-availability, with no increase in the extracted concentration and no increased shoot concentration for these elements. Significant quantities of B were added in the sludge, but stability of organic complexes precluded any change in extraction and uptake. For $\mathrm{Zn}$, the quantity added was too low to register a response. Caution should be taken in the interpretation of DTPA-extractable $\mathrm{Cu}$ and DTPA-extractable Mn as measures of bioavailability. Increased Mn uptake appeared to be dictated by soil conditions rather than by the quantity of Mn added. In contrast, increased DTPA-extractable $\mathrm{Cu}$ was pronounced following sludge amendments, but plant uptake of $\mathrm{Cu}$ did not change, suggesting elevated $\mathrm{Cu}$ uptake is prevented by maize root physiology, even at elevated rhizosphere concentrations. Stability of root $\mathrm{Cu}$ concentration among treatments indicates that $\mathrm{Cu}$ uptake to roots was prevented, rather than uptake to roots 
having occurred without transfer to shoots. Overall, these results illustrate that significant quantities of micronutrients in a readily mineralized sludge material can, but do not necessarily, cause increases in available levels of those micronutrients as determined by soil extraction or crop uptake, with modifying influences from soil conditions and root selectivity.

\section{Acknowledgement}

Thanks to Karen Krywko and Nancy Dolbeck for technical assistance. This project was supported by research funds supplied by Third High Farms, Iroquois, Ontario, Canada.

\section{References}

Abdou, F. M., \& El-Nennah, M. (1980). Effect of irrigating loamy sand by liquid sewage sludge on its content of some micronutrients. Plant and Soil, 56, 53-57. http://dx.doi.org/10.1007/BF02197952

Barbarick, K. A., \& Workman, S. M. (1987). Ammonium bicarbonate-DTPA and DTPA extractions of sludge-amended soils. Journal of Environmental Quality, 16, 125-130. http://dx.doi.org/10.2134/jeq1987.00472425001600020006x

Bell, R. W. (1997). Diagnosis and prediction of boron deficiency for plant production. Plant and Soil, 193, 149-168. http://dx.doi.org/10.1023/A:1004268110139

Bidwell, A. M., \& Dowdy, R. H. (1987). Cadmium and zinc availability to corn following termination of sewage sludge applications. Journal of Environmental Quality, 16, 438-442. http://dx.doi.org/10.2134/jeq1987.00472425001600040025x

Binder, D. L., Dobermann, A., Sander, D. H., \& Cassman, K. G. (2002). Biosolids as nitrogen source for irrigated maize and rainfed sorghum. Soil Science Society of America Journal, 66, 531-543. http://dx.doi.org/10.2136/sssaj2002.5310

Brady, N. C., \& Weil, R. R. (2008). The nature and properties of soils. (14th ed.). Upper Saddle River, NJ: Prentice Hall.

Bromfield, S. M., Cumming, R. W., David, D. J., \& Williams C. H. (1983). Change in soil pH, manganese, and aluminium under subterranean clover pasture. Australian Journal of Experimental Agriculture and Animal Husbandry, 23, 181-191. http://dx.doi.org/10.1071/EA9830181

Cerrato, M. E., \& Blackmer, A. M. (1990). Comparison of models for describing corn yield response to nitrogen fertilizer. Agronomy Journal, 82, 138-143. http://dx.doi.org/10.2134/agronj1990.00021962008200010030x

Chaignon, V., \& Hinsinger, P. (2003). A biotest for evaluating copper bioavailability to plants in a contaminated soil. Journal of Environmental Quality, 32, 824-833. http://dx.doi.org/10.2134/jeq2003.8240

Davis, R. D. (1993). Agricultural utilization of sewage sludge. In: Agriculture and the Environment (edited by: J. G. Jones), Ellis Horwood, Chichester, U. K., 17-25. 
del Val C., Barea, J. M., \& Azcon-Aguillar, C. (1999). Assessing the tolerance to heavy metals of arbuscular mycorrhizal fungi isolated from sewage sludge-contaminated soils. Applied Soil Ecology, 11, 261-269. http://dx.doi.org/10.1016/S0929-1393(98)00153-X

Evans, L. J., Spiers, G A., \& Zhao, G. (1995). Chemical aspects of heavy metal solubility with reference to sewage sludge amended soils. International Journal of Environmental Analytical Chemistry, 59, 291-302. http://dx.doi.org/10.1080/03067319508041335

Flores-Valez, L. M., Ducaroir, J., Jaunet, A. M., \& Robert, M. (1996). Study of the distribution of copper in an acid sandy vineyard soil by three different methods. European Journal of Soil Science, 47, 523-532. http://dx.doi.org/10.1111/j.1365-2389.1996.tb01852.x

Fujita, Y., Hata, T., Nakamaru, M., Iyo, T., Yoshino, T., \& Shimamura, T. (2005). A study of boron adsorption onto activated sludge. Bioresource Technology, 96, 1350-1356. http://dx.doi.org/10.1016/j.biortech.2004.11.008

Gilmour, J. T., Cogger, C. G., Jacobs, L. W., Evanylo, G. K., \& Sullivan, D. M. (2003). Decomposition and plant-available nitrogen in biosolids: laboratory studies, field studies, and computer simulation. Journal of Environmental Quality, 32, 1498-1507. http://dx.doi.org/10.2134/jeq2003.1498

Goda, T., Kuboi, T., \& Fujii, K. (1986). Environmental impacts of sewage sludge applied to cropland. Internat. Journal of Environmental Studies, 27, 239-253. http://dx.doi.org/10.1080/00207238608710293

Goldberg, S. (1997). Reactions of boron with soils. Plant and Soil, 193, 35-48. http://dx.doi.org/10.1023/A:1004203723343

Gupta, U. C. (1967). A simplified method for determining hot-water soluble boron in podzol soils. Soil Science, 103, 424-428. http://dx.doi.org/10.1097/00010694-196706000-00009

Hue, N. V., Silva, J. A., \& Arifin, R. (1988). Sewage sludge-soil interactions as measured by plant and soil chemical composition. Journal of Environmental Quality, 17, 384-1390. http://dx.doi.org/10.2134/jeq1988.00472425001700030007x

Ito, A., Umita, T., Aizawa, J., Takachi, T., \& Morinaga, K. (2000). Removal of heavy metals from anaerobically digested sewage sludge by a new chemical method using ferric sulfate. Water Research, 34, 751-758. http://dx.doi.org/10.1016/S0043-1354(99)00215-8

Jiang, Y., Qin, Y., Zhang, Y., Li, Q., \& Liang, W. (2008). Spatial heterogeneity of soil DTPA-extractable copper as affected by city pollution and land use in cultivated fields of Shenyang, China. American-Eurasian Journal of Agriculture and Environmental Science, 4, 294-301.

Jones, J. B., Eck, H. V., \& Voss, R. (1990). Plant analysis as an aid in fertilizing corn and sorghum. In: Soil testing and plant analysis (edited by: R. L. Westerman), Soil Science Society of America, Madison, W. I., 521-547.

Ketcheson, J. W. (1980). Effect of tillage on fertilizer requirements for corn on a silt loam soil. Agronomy 
http://dx.doi.org/10.2134/agronj1980.00021962007200030031x

Kunito, T., Saeki, K., Goto, S., Hayashi, H., Oyaizu, H., \& Matsumoto, S. (2001). Copper and zinc fractions affecting microorganisms in long-term sludge-amended soils. Bioresource Technology, 79, 135-146. http://dx.doi.org/10.1016/S0960-8524(01)00047-5

Liang, J., \& Karamanos, R. E. (1993). DTPA-extractable Fe, Mn, Cu, and Zn. In: Soil sampling and methods of analysis (edited by: M. R. Carter), Lewis, Boca Raton, F. L., 87-90.

Marschner, H. (1995). Mineral nutrition of higher plants. (2nd ed.). London, U.K.: Academic Press.

Matsi, T., Antoniadis, V., \& Barbayiannis, N. (2000). Evaluation of the $\mathrm{NH}_{4} \mathrm{HCO}_{3}$-DTPA soil test for assessing boron availability to wheat. Communications in Soil Science and Plant Analysis, 31, 669-678. http://dx.doi.org/10.1080/00103620009370468

McGonigle, T. P., Beauchamp, E. G, Evans, L. J., \& Wells, C. J. (2012). Mineralization and crop uptake of nitrogen from textile manufacturing wastewater sludge cake. Applied and Environmental Soil Science. http://dx.doi.org/10.1155/2012/273456

McGrath, S. P., Brookes, P. C., \& Giller, K. E. (1988). Effects of potentially toxic metals in soil derived from past applications of sewage sludge on nitrogen fixation by Trifolium repens

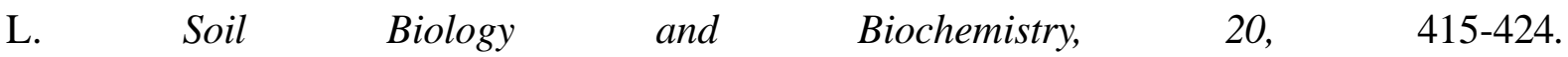
http://dx.doi.org/10.1016/0038-0717(88)90052-1

McGrath, S. P., Chaudri, A. M., \& Giller, K. E. (1995). Long-term effects of metals in sewage sludge on soils, microorganisms and plants. Journal of Industrial Microbiology, 14, 94-104. http://dx.doi.org/10.1007/BF01569890

Perez-Murcia, M. D., Moral, R., Moreno-Caselles, J., Perez-Espinosa, A., \& Paredes, C. (2006). Use of composed sewage sludge in growth media for broccoli. Bioresource Technology, 97, 123-130. http://dx.doi.org/10.1016/j.biortech.2005.02.005

Reddy, M. R., \& Dunn, S. J. (1983). Heavy metal and micronutrient uptake in soybeans as influenced by sewage sludge amendment. Science of the Total Environment, 30, 85-98. http://dx.doi.org/10.1016/0048-9697(83)90004-9

Sah, R. N., \& Brown, P. H. (1997). Techniques for boron determination and their application to the analysis of plant and soil samples. Plant and Soil, 193, 15-33. http://dx.doi.org/10.1023/A:1004251606504

Sharma, B. D., Mukhopadhyay, S. S., Sidhu, P. S., \& Katyal, J. C. (2000). Pedospheric attributes in distribution of total and DTPA-extractable $\mathrm{Zn}, \mathrm{Cu}, \mathrm{Mn}$, and $\mathrm{Fe}$ in Indo-Gangetic plains. Geoderma, 96, 131-151. http://dx.doi.org/10.1016/S0016-7061(00)00008-2

Sims, J. T., \& Johnson, G. V. (1991). Micronutrient soil tests. In: Micronutrients in agriculture (2nd ed.) (ed. by: J. J. Mortvedt), Soil Science Society of America, Madison, W. I., 427-476.

Sommer, L. E. (1977). Chemical composition of sewage sludges and analysis of their 
potential use as fertilizers. Journal of Environmental Quality, 26, 225-232. http://dx.doi.org/10.2134/jeq1977.00472425000600020026x

Thomas, R. L., Sheard, R. W., \& Moyer, J. R. (1967). Comparison of conventional and automated procedures for nitrogen, phosphorus, and potassium analysis of plant material

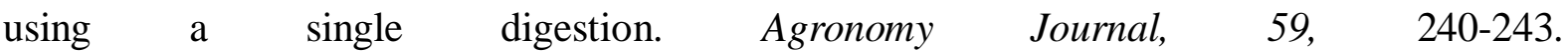
http://dx.doi.org/10.2134/agronj1967.00021962005900030010x

Tisdale, S. L., Nelson, W. L., Beaton, J. D., \& Havlin, J. L. (1985). Soil fertility and fertilizers. (5th ed.). New York: Macmillan.

Tollenaar, M., Dibo, A. A., Aguilera, A., Weise, S. E., \& Swanton, C. J. (1994). Effect of crop density on weed interference in maize. Agronomy Journal, 86, 591-595. http://dx.doi.org/10.2134/agronj1994.00021962008600040003x

Vazquez, C., Barbaro, N., \& Lopez, S. (2003). XRF analysis of micronutrients in endive grown on soils with sewage sludge. X-Ray Spectrometry, 32, 57-59. http://dx.doi.org/10.1002/xrs.580

Wen, G., Bates, T. E., Voroney, R. P., Yamamoto, T., Chikushi, J., \& Curtin, D. (2002). A yield control approach to assess phytoavailability of $\mathrm{Zn}$ and $\mathrm{Cu}$ in irradiated, composted sewage sludges and composted manure in field experiments: I. Zinc. Plant and Soil, 246, 231-240. http://dx.doi.org/10.1023/A:1020661225434

Wen, G., Bates, T.E., Inanaga, S., Voroney, R. P., Hamamura, K., \& Curtin, D. (2002). A yield control approach to assess phytoavailability of $\mathrm{Zn}$ and $\mathrm{Cu}$ in irradiated, composted sewage sludges and composted manure in field experiments: II. Copper. Plant and Soil, 246, 241-248. http://dx.doi.org/10.1023/A:1020665309504

Whitby, L. M., Gaynor, J., Maclean, A. J. (1978). Metals in soils of some agricultural watersheds in Ontario. Canadian Journal of Soil Science, 58, 325-330. http://dx.doi.org/10.4141/cjss78-039

Wolf, B. (1971). The determination of boron in soil extracts, plant materials, composts, manures, water, and nutrient solutions. Communications in Soil Science and Plant Analysis, 2, 363-374. http://dx.doi.org/10.1080/00103627109366326

Wu, J. M., Wang, K., Bell, R. W., Yang ,Y. A., \& Huang, L. B. (2001). Soil boron fractions and their relationship to soil properties. Soil Science Society of America Journal, 65, 133-138. http://dx.doi.org/10.2136/sssaj2001.651133x

Yermiyahu, K. R., \& Chen, Y. (1995). Boron sorption by soil in the presence of composted organic matter. Soil Science Society of America Journal, 59, 405-409. http://dx.doi.org/10.2136/sssaj1995.03615995005900020019x

Zar, J. H. (2010). Biostatistical analysis. (5th ed.). Upper Saddle River, N.J.: Prentice Hall.

\section{Glossary}

AAS: atomic absorption spectroscopy 
DTPA: diethylene triamine pentaacetic acid

ICP: inductively coupled plasma

OES: optical emission spectroscopy 